\title{
Crossing American Borders: Reclaiming Palestinian National and Cultural Identities in Ibrahim Fawal's On the Hills of God
}

\author{
Nagwa Ibrahim Dawoud*
}

\section{Introduction}

Ibrahim Fawal was born in Ramallah in 1933 and was forced into exile after the Palestinian nakba (catastrophe) in 1948. He travelled to the United States and received a Master's degree in film-making. He worked with the prominent film director David Lean as "the 'Jordanian' first assistant director on the classic Lawrence of Arabia [1962]" ("About" 2006, 448). Fawal resided in Birmingham, Alabama, where he taught film-making and literature at Birmingham-Southern College and the University of Alabama at Birmingham (448). After 50 years of the painful memory of the Palestinian nakba, Fawal published his first literary work On the Hills of God (1998) which won the PEN Oakland Award for excellence in literature. Literature, as Susan Sontag indicates, is ultimately a dialogue and a mode of responsiveness, since one of its essential tasks is "to formulate questions and construct counterstatements to the reigning pieties" (qtd. in Popova 2013, n. pag.). This applies very well to Fawal's novel, which as this paper argues, has efficiently managed to construct such 'counterstatements' to the dominant anti-Palestinian discourse in America. The struggle against Zionist settler colonialism as a representation of a 'reigning piety' in Palestine necessitates writing back, reclaiming one's own history, culture, and identity. This is what Fawal attempts to do for Palestine by his novel after crossing American borders and living in exile.

Exiled in America, Fawal never ceased to be haunted by childhood and adolescence memories in Ramallah through an unending cycle of tyranny and injustice, which constitutes the constant struggle most Palestinians have lived

\footnotetext{
* Ph.D. candidate in the Department of English Language and Literature, Faculty of Arts, Cairo University. This paper is derived from her Ph.D. thesis in-progress, entitled "Reclaiming National and Cultural Identity in Selected Irish and Palestinian Literary Works" (Cairo University), supervised by Prof. Amal Mazhar and Prof. Mona Moenes. Cairo Studies in English 2020(2): https://cse.journals.ekb.eg/
} 
through since the mid-20th century until the present moment. The prominent Palestinian critic and writer, Jabra Ibrahim Jabra, reflects on the state of being in exile, or the 'forced' crossing of borders asserting that

the sense of loss in an exile is unlike any other sense of loss. It is a sense of having lost a part of an inner self, a part of an inner essence. An exile feels incomplete even though everything he could want physically were at his fingertips. He is obsessed by the thought that only a return home could do away with such a feeling, end the loss, reintegrate the inner self. $(1979,83)$

Thus, with the persistence of the Palestinian issue, Fawal's novel is a remarkable contribution to the cause being the first fictionalized English-language account of the nakba, the 'catastrophe' which befell the Palestinian nation once the state of Israel was being declared on the lands of Palestine. The events taking place in the novel start in June 1947, "Palestine's last summer of happiness" (Fawal 1998, 1). It is the last summer before the United Nations' Partition Resolution divided Palestine into an Israeli state next to an Arab one. Thus, it marks the last summer before thousands of Palestinians would lose almost everything and start an odyssey of misery whether inside Israel, in refugee camps, or crossing borders, forming a world-wide diaspora.

The experience of diaspora is central to Palestinian nationalism. Joe Cleary believes that the political weight exercised by Palestinians exiled in Arab and Islamic societies as well as in the US represents a "significant version of what Benedict Anderson has termed 'long-distance nationalism"' $(2002,6)$. These diasporas have helped to keep the Palestinian issue on the international agenda despite the vicious pressure by the Zionist lobby in the US to put the Palestinian question into oblivion or to misrepresent it by derogatory stereotypes. Although being an Israeli himself, Ilan Pappé, criticizes the stereotypical representation of Palestinian nationalism as one of terrorism in Israeli media, academic circles, and the political 'elite' in international arenas $(2009,127)$. He states that in the West, this image was accepted in many circles and affected the chances of the Palestinians having a fair hearing in the peace negotiations which began after the 1967 War. Pappé traces the construction of equating Palestinian nationalism with terrorism, and suggests the deconstruction of this narrative as the best way forward in future peace negotiations. According to Pappé, "the Israeli orientalists, especially after $9 / 11$, strove to reaffirm in the public mind in Israel and abroad the association between Islam and Palestine, Islam and Terror or 
more specifically 'the War against Terror' with the Israeli struggle against Palestinian nationalism" (129).

Bill Ashcroft rightly indicates that in the case of diasporic peoples, 'place' might not refer to a location at all, since the formative link between identity and an actual location might have been severed. Accordingly, the place of "a diasporic person's 'belonging' may have little to do with spatial location, but be situated in family, community, in those symbolic features which constitute a shared culture, a shared ethnicity or system of belief, including nostalgia for a distant homeland. It is when place is least spatial, perhaps, that it becomes most identifying" $(2001,125)$. This is similarly the case with Fawal's place (Palestine) being 'least spatial;' it is out of his reach as the formative link between him and his actual location has been severed by Israeli colonialism. Thus, belonging to Palestine for Fawal has little to do with the spatial location of Palestine, his distant homeland. Instead, it exists in the memories of the symbolic features that constitute a shared culture and ethnicity. This kind of belonging as Ashcroft mentions becomes most identifying. Thus, this paper will examine how Fawal narrates his personal memories and the symbolic cultural features of Palestine to reclaim his homeland with all its intricate details. In doing so, he significantly affirms the national and cultural Palestinian identities whilst deconstructing the stereotypical Israeli narrative of Palestine and the Palestinians, eventually offering a different perspective to the American readers.

The novel represents a major contribution to Palestinian literature fighting for the Palestinian cause in the West, especially the US. In the forward to his seminal book Discourse and Palestine: Power, Text and Context (1995), Ibrahim AbuLughod states that the battle for determining the fate of Palestine and the Palestinians has always transcended the frontiers and borders of Palestine and the Arab world; it was fought first in Europe and then in the US (Abu-Lughod 1995, 1). Published in English in the US further stresses the novel's intended audience and its global outreach. Robin Ostle elaborates that other Palestinian authors such as Ghassan Kanafani and Emile Habibi whose Arabic novels have been translated into English do not necessarily receive similar visibility since they "have remained locked within the specialized circles of Arabists and Middle Eastern scholars" (2006, 7).

Moreover, Fawal's novel has received worldwide recognition as it has been translated into several other languages. Reviews of the novel similarly highlight how it helps clarify what the Palestinians have actually suffered and provides a necessary understanding of the roots of the Palestinian issue. In his review of the novel in The Washington Post, Michael Lee maintains that the depth of feeling 
emanating from Fawal in this powerful work leaves the reader "with so much to consider and react to after the last page is turned that one cannot escape the realization that this is truly a stunning creation" $(1999,124)$. Lee adds that for readers who are too far removed in time or space, and who wish "to have comprehended at first-hand the nakba, or 'catastrophe' that deprived the Palestinians of their homes, their lands, their rights and even human compassion, this is the book that will provide that understanding" (124). Similarly, Clare Brandabur affirms that every American could learn something from such a dispassionate novel; once audiences read the novel, "they can no longer say they did not know what happened to the Palestinians in 1948. Perhaps the narrative of what happened to the Palestinians can now be seen as having a great deal to do with our own narrative as Americans and has something to tell us about who we really are as well " (Brandabur 2002, 86).

The rise of Palestinian intellectuals in American academic and media circles has often generated vicious attacks, nevertheless, as Ella Shohat elaborates on how Edward Said was attacked by Edward Alexander in 1989 in his article "Professor of Terror." However, their contribution in creating a counter discourse to the hegemonic Israeli discourse dominant in the US is, nevertheless, highly essential. It could be said that Edward Said himself is one of the border crossers who crossed not only American borders, but world borders to build bridges of understanding and support for the Palestinian cause. Shohat rightly points out that Palestinian intellectuals in the US are situated on the fragile borders separating culture, nationalities, and discourses; they write about the 'East' in the 'West' $(1995,221)$. Despite their integration within the Western culture, the Arab diaspora still speak from the 'margins' designated as 'third world' voices. Burdened with the weight of representing the Palestinian perspective, they have attempted to "transgress the Israeli national narration, to break the asymmetrical representations between Israel and Palestine in the United States, and to introduce an alternative to the Zionist master narrative" (221). Being one of those burdened intellectuals, Fawal, as a discourse maker, is producing a counter narrative to the Israeli one which represents a national version of the land of Palestine before the advent of Zionist colonialism.

Thus, after geographically crossing the American borders as an exiled Palestinian, Fawal seeks, through his novel, to cross the borders of misunderstanding by offering an authentic narration of his homeland that subvert the false representations of Palestine for the American readership. Therefore, through his novel, he metaphorically crosses the borders back to Palestine. $\mathrm{He}$ crosses spatial and temporal borders to a disfigured image about Palestinians and 
to defy barriers of misunderstanding that deprive Palestinians of their rights and escalate their misery. Through the novel, Fawal narrates to symbolically cross the borders back and return to his cherished homeland. Working within the paradigms of border studies, memory, and postcolonial studies, this paper attempts to examine how Fawal creates an 'archive' that reclaims Palestinian national and cultural identities in his novel.

\section{Historical and Theoretical Backgrounds}

Geographically located in the eastern Mediterranean region, Palestine is at the crossroads of three continents, the 'heart' of the Old World. Gudrun Krämer observes that Palestine was always a land of passage because of its location as part of the fertile crescent stretching from the Mediterranean to the Persian Gulf and from the Taurus and Zagros Mountains in the north to the Arabian Desert in the south $(2008,1)$. Historically, Palestine was often referred to as the 'Holy Land,' a sacred entity for the three Abrahamic religions. Being so sacred, it has been the object of conflicting claims and countless vicious wars. Since the Middle Ages being the battlefield of the Crusades, Palestine, in modern history, has equally gone through a long painful history of settler colonialism under the British and Israeli enterprises. According to Joseph Massad, the 1948 War became known in Israeli ideological pronouncement as a "war of independence" and the officially named "Declaration of the Establishment of the State of Israel" was renamed in popular discourse as the "Declaration of Independence" (2006, 19). For the Palestinians, it was a 'catastrophe' that signaled the loss of their ancestral homeland and caused an 'identity-wound' for all Palestinians. Michael Prior points out that Israeli public relations and propaganda in collaboration with Zionist ideologues and historiographers succeeded in masking the fact that "the creation of Israel resulted in the dispossession and dispersion of another people, and that dispossession was the result of formal planning and ruthless execution" $(2005,14)$. Prior asserts that the events that unfolded after 1948 should be viewed within the "paradigm of ethnic cleansing: when Israel took almost $80 \%$ of Palestine, it did so through ethnic cleansing of the original population making it a community of victims" (15). Thus, as 'a community of victims,' Palestinians were forced into a diasporic existence, whether being internally exiled inside Israel itself, in refugee camps in nearby countries, or crossing further borders into different parts of the world.

In order to fathom the extent of Fawal's contribution in reaching out to the American readership, it would be interesting to read Edward Said's view in which he laments "the silence, indifference and non-involvement of the Western 
world [which] perpetuate the suffering of a people who have not deserved such a long agony" (Said 1979, xxi). Thus, through their literary productions, Fawal and other Palestinian authors attempt to defy such a complex situation in which Palestinians survive. They construct a political identity that defies 'nonexistence.' Hence, Said affirms, "we have been united as a people because the Palestinian idea (which we have articulated out of dispossession and exclusionary oppression) has a coherence to which we have all responded with positive enthusiasm" (1979, xxxvi). He rightly maintains that the Palestinian cause remains "the one uncooptable, undomesticated, and fierce national and anti-colonial cause still alive - to its adherents a source of unrealized hope and somewhat tarnished idealism, to its enemies a goad and a perdurable political ego that will neither go away nor settle into amiable nonentity" (xxviii).

\section{Border Studies, Memory, and Postcolonial Studies}

Theoretically, this study adopts an interdisciplinary approach, working within the paradigms of border, cultural, memory and postcolonial studies. Sergei Sevastianov et al. emphasize that it was mainly geographers and, to a lesser extent, historians, who played a pioneering role in early border studies $(2015,6)$. For contemporary scholars of border studies, the attention has shifted from the actual borderline, its geography, its delimitations and demarcations, to cover a variety of forms and types of social boundaries, in both their material and symbolic dimensions (7). Vladimir Kolosov points out that by the end of the last century, Border Studies, became a rapidly widening interdisciplinary field of knowledge $(2015,33)$. Borders are not merely geographical or political; they often exist within the same geopolitical entity. Thus, scholars often refer to the concept of a 'symbolic boundary,' as Anatolii Kuznetsov further elaborates while examining social, cultural, racial, and religious boundaries. Other cultural, anthropological, and ethnographic aspects are also essential to the study of boundaries in general (Kuzetsov 2015, 93).

The focus of border studies has developed from studying borders as delimiters of territorial control and ideology towards a more dynamic role of borders as bridges rather than barriers (Sevastianov et al. 2015, 7). For Claudia Smith, a border is a meeting place, a point of contact for diverse cultures and histories $(2002,1)$. She points out that within cultural critique, notions of borders and border crossing have become synonymous with diasporic formation since border scholarship has paved the way for diaspora studies that have focused on experiences of displacement and cultural hybridity that link racialized groups in the US to their third world countries or areas of origin. Smith rightly elaborates 
that members of diaspora become conduits for the flow of information, images, and ideas across national boundaries. Their literal or symbolic forms of transborder movement undermine oppressive nation states and oppressive ideologies (3). If we try to relate this to Fawal, it could be said that he uses the American border as a point of contact, as a meeting place where he can narrate his people's culture and history on their land of Palestine. Hence it could also be inferred that as a member of the Palestinian diaspora himself, Fawal - through his novel - is one of those 'conduits' for the flow of images and knowledge about Palestine for the Americans. As a result, he efficiently defies and undermines Israel's oppressive colonial ideology.

In relation to cultural studies, Stuart Hall defines it as a discursive formation that is connected to matters of power and politics, and "to the need for change and to representations of and 'for' marginalized social groups" $(1992,278)$. Furthermore, according to Chris Barker, cultural studies is "a body of theory generated by thinkers who regard the production of theoretical knowledge as a political practice. Here knowledge is never a neutral or objective phenomenon but a matter of positionality, of the place from which one speaks, to whom, and for what purposes" $(2000,5)$. Hall emphasizes that questions of culture are thought of through metaphors of language, textuality, intertextuality of texts, and of texts as sources of meaning and power. Culture is also viewed through the multiplicity of meanings offered through textuality as a site of representation and resistance, and where the symbolic is a source of identity $(1992,784)$. For Hall, identity is about using the resources of history, language, and culture to explore how people are represented and, consequently, how they might represent themselves; identities are, therefore, "constituted within, not outside representation. They arise from the narrativization of the self" $(1996,4)$. Similarly, Fawal presents the Palestinian identity through his novel using the rich reservoir of Palestinian history, language, and culture to represent his people and their cause to the whole world - not only the American reader - in a way that helps Palestinians cross borders of misunderstanding and to construct bridges of understanding and support for their cause instead.

As for memory studies, Michael Rossington and Anne Whitehead maintain that memory studies extend to the fields of literary, cultural, and historical discourses. They refer to the link between the rise of memory studies and identity politics $(2007,10)$. Within the field of memory studies, memory has its significant function in "humans' consciousness of themselves as having distinct identities over time" (2). Memory, with its significant role in defining subjectivities, is also vital for nation building. It is important, thus, to observe 
the intersection of individual and collective memories in nation building. Rossington points out that collective memory plays an important functioning role, distinct from history, in conceiving a society's past (Rossington and Whitehead 2007, 135). Memory is also central to postcolonial studies because of the ways in which personal and cultural memories can be used to analyze and undermine the structures of empire (9). Hence, through his novel, Fawal uses memories of his homeland as an anti-colonial strategy to dismantle and subvert the Israeli colonial discourse about Palestine.

\section{Place, Memory, and National Identity}

Place is the horizon of identity; it is where people locate, define, and understand their identity. Place, as Barker affirms, is, therefore, the focus of human experience, memory, desire, and identity (2000, 293). Moreover, identifying one's 'place' is fundamental to the cultural impact of colonization and affects every aspect of colonized societies (Ashcroft 2001, 124). However, place is never simply a location, nor is it static, or a minor detail which colonization could easily obliterate. Like culture and identity, place is in a continual and dynamic state of formation, a process which is, for Ashcroft, intimately bound up with the culture and the identity of its inhabitants (2001, 124). It forms itself out of "the densely woven web of language, memory and cultural practice and keeps being formed by the process of living" (156). Through writing, colonized places are re-inscribed, decolonized and reclaimed; the identity of the colonized place with all its details is reclaimed in literary representations of colonized places by native writers. Ashcroft clarifies that it is in "the creative reconstruction of the lived environment, the reassertion of place in language and textuality, that the key to a deep-seated cultural transformation may be found" (124). This paper examines how such re-inscription and reclaiming of the colonized Palestinian places and, hence, the national and cultural identities of these places have been addressed in Fawal's novel.

The story takes place in 1947 and 1948, in the fictional village of 'Ardallah' (Arabic for 'the land of God'). Yousif Safi is the protagonist who spends all his time happily with his two best friends, Amin and Isaac. Christian, Muslim, and Jewish respectively, their entire lives were turned upside down with the establishment of the State of Israel. Seventeen-year-old Yousif is in love with his family, his friends, his pretty neighbor Salwa and, foremost, with his homeland, Palestine. Events escalate and Yousif's father is killed. Yousif, his mother, and now his wife, Salwa - like all other Palestinians - are expelled from their cherished houses and beloved homeland. The novel ends with Yousif, who 
loses his wife Salwa during the miserable Palestinian exodus, and his mother accepting the first refuge they find in Amman, a bare room in a Jordanian house, without money, without a source of livelihood, facing a future of exile, but Yousif promises to recover the 'stolen' family house and homeland.

Embedded cleverly within the narrative are the daily lives of Palestinians, their life which involves customs, habits, food, celebrations, music, clothes, cooking methods, rituals, education system, housing, streets, and cities, all portrayed with their original Arabic names, thus, pointing to their solid historical existence inside Palestine. Therefore, this novel represents an archive of the Palestinians, their identity, and their usurped land's identity. The reader, as Robin Ostle notes, is transported to a culture where friends and families, and people in general express their existence through their connectedness to the land of Palestine, where, the labels Muslim, Christian, and Jew are all designated as Palestinians $(2006,8)$. The title of the novel is borrowed from Jamal, the blind musician who teaches Isaac to play the oud, when he once passionately describes the hills of Palestine as the hills of God. Ostle brilliantly indicates that on the pages of the novel, the hills, the countryside, the vegetation, the fruit, and the produce of the land have presences as vital as those of the human characters. He rightly believes that the novel is a testimony

[a]t once moving and shocking, that the Palestine that was destroyed in 1948 was a rich and delicate human fabric which has been built over many generations. Muslims, Christians, and Jews shared a common language - Arabic - and a common culture and they shared the land. That delicate fabric was destroyed rapidly and brutally creating a massive injustice. On the Hills of God is a recreation in literature of the human beings that were Palestine before 1948, most of whom now live under occupation or scattered in diasporas. (8)

Through the novel, the reader feels the painful destruction of 'once upon a time Palestine,' and realizes how painful it is for Palestinians these days to see Palestinian places with new names, different people, and a different identity that denies Palestinians altogether. Nevertheless, the reader still senses the figurative reclaiming of the national and cultural identities of the Palestinians' usurped places and homeland. Bhabha rightly contends that nationalist discourses are performative, he points out that "the scraps, patches and rags of daily life must be repeatedly turned into the signs of a national culture" (Bhabha 1990, 297). This is similarly the case in this novel, where we discover the diverse 'scraps' 
and 'patches' of the Palestinians' daily lives on their lands prior to the Israeli colonial presence. Reviving the memory of such daily life details is a remarkably effective strategy; such a narration of daily mundane existence serves as an anticolonial resistance.

\section{Pre-Colonial Memory of Ardallah}

The pre-colonial memory of Ardallah is an effective anti-colonial strategy. As a fictional place, Ardallah, for many critics, is very much like Ramallah, the author's birthplace (ard is Arabic for "land," with the added connotation of the sacred name Allah, which Arabs from the three main religions use for God, it is the land belonging to God). Ardallah combines characteristics common to the land of Palestine as a whole, thus, both a land and culture that combine the three Abrahamic religions. This is very clear through the three young Palestinian friends who are in their last year of high school, "Yousif was Christian, Amin Muslim, Isaac Jewish. [...] They had gone through elementary and secondary school together. Together they had switched from shorts to pants. [...] They were so often together that the whole town began to accept them as inseparable" (Fawal 1998, 16).

Early in the novel, Fawal reclaims the identity of Palestine as the land of the three religions. Jews were treated well and integrated in the Arab culture of Palestine, unlike the persecution and isolation they often struggled with within some Western cultures. Fawal highlights this fact through Dr. Jameel Safi, Yousif's father, who tells Yousif and Isaac that Yousif's mother nursed both of them for over a month; "[so] in a sense you're brothers" (1998, 122). Sara, Isaac's mother, asserts that Zionists who came from Europe "looked for ways to stop us from mixing with the Arabs" (122). Dr. Jameel then remarks, "in Jerusalem, there used to be a tradition among Jews and Muslims. Children of both faiths who were born on the same day were breasted by both mothers. And they used to take this relationship very seriously" (122). Moshe, Isaac's father, further comments: "but in the late twenties, that was the first thing the Zionists stopped. They did not want the two communities to mingle" (123). Thus, Fawal is writing back in an attempt to reclaim the identity of not only Jerusalem, but the whole of Palestine, people from different religions used to live together in harmony and only when Europeans imposed themselves, did things fall apart.

By the end of the novel, Fawal even stresses this through the dialogue between Yousif and his school principal Ustaz Saadeh when Yousif tells him that "the West persecuted the Jews" and he replies, "We didn't" (374). Saadeh's answer documents a fact that maybe several readers did not know about; he adds: 
"well, of course. And not only the Germans. The Russians, Spanish, French, and British before them. Britain threw them out for centuries. America won't even let them join her country clubs. Your father and I were in America and we know their gentlemen's agreement" (374). Memory, thus, plays a pivotal role in subverting the hegemony of colonial history by offering alternative versions of established archives (Rossington and Whitehead 2007, 9). Furthermore, collective memory plays an important functioning role, distinct from history, in conceiving a society's past. Similar personal and collective memories in the novel documenting how Jews were treated in Palestine, in contrast to how they were often treated in the West, offer a counter discourse to the Israeli hegemonic discourse that denies such facts.

\section{Reclaiming Palestinian Character and Geography}

In depicting Yousif, Amin, Issac, Dr. Jameel, Ustaz Saadeh, and many other characters, Fawal is dismantling misrepresentations and stereotypes about Palestinians that were created by the Israeli colonial discourse. In his seminal book The Question of Palestine (1979), Said observes that since its founding, Israel has enjoyed "an astonishing dominance in matters of scholarship, political discourse, international presence, and valorization. ... Its miraculous transformation of an 'arid and empty land' gained universal admiration" (xiv). In accordance with this, Israel has been taken to represent the best in the Western and Biblical traditions; citizens of Israel were soldiers, farmers, scientists and artists. In contrast, Palestinians were seen as "Arabs" or anonymous creatures that only disrupt and disfigure a wonderful idyllic narrative. Even in children's literature, Said notes that valiant Jews always end up killing deceitful Arabs with derogatory names like Mastoul (crazy), Bandura (tomato), or Bukra (tomorrow). As for Palestinian acts of resistance, Said elaborates, Israeli politicians, soldiers, diplomats, and intellectuals characterize Palestinians as terrorists and nonhuman "cockroaches, grasshoppers, two legged vermin" (xxi). Against these derogatory stereotypes, Fawal depicts his characters as ambitious students - such as Yousif who wishes to pursue his education like his father in Columbia University in the USA -, teachers, lawyers, doctors, and artists etc., in order to subvert the Israeli colonial narrative that denies their existence. However, when Golda Meir, the former Israeli prime minister, was often asked about Palestinians: "Who are the Palestinians?" she repeatedly answered, "There is no such thing" (qtd in Kayyali 1977, 111).

Moreover, intentionally depicting the intricate details of Palestinians' lives in their homeland Ardallah, Fawal portrays how doctor Jameel Safi is seen 
celebrating moving to his new modern prestigious villa with the people of Ardallah after ten years of preparation on the Palestinian land. Land or ard in Arabic is the core of the Palestinian identity. According to Fawaz Turki, the land, as a real entity and a metaphor, is the most dominating presence in Palestinian literature; "Landhood," as he coins it, "is the raison d'être of Palestinian being and consciousness" (Turki 1981, 373). Hence, Fawal reclaims the Palestinian spatial identity through depicting the geography of Ardallah which

was a town thirty miles northwest of Jerusalem and fifteen miles east of Jaffa. [...] Only Ramallah, a town fifteen miles to the east and a better-known resort, surpassed Ardallah in the number of vacationers who arrived every summer. [...] They came to Ardallah from the seashores of Jaffa and Haifa, and from the fertile fields and orchards of Lydda and Ramleh. [...] Ardallah sat as a crown on seven hills from which could be seen a spectacular panorama of rolling hills and, on a clear day, a glimpse of the blue Mediterranean waters. (Fawal 1998, 19-20)

Thus, in reclaiming the geography of Palestine, the memory of such places, their location, and the insertion and affirmation of these Arabic names is a counter discourse to the Israeli colonial discourse that has presented Palestine as a desert, a waste land, sparsely populated by Bedouins. He also resists the change imposed on the topography of the land, and which even referred to Palestinian places using Hebrew names. Ardallah, which one can consider as a metaphor for the whole of Palestine, was a prestigious modern place. It had prestigious institutions: schools for boys and girls, mosques, churches, banks, clubs, restaurants, and hotels. It was not a waste land, or a desert waiting for Zionists to make it bloom.

This depiction of Ardallah is very significant as it represents a counter discourse to the Zionist myth that proclaims Palestine as 'a land without a people to be given to a people without a land.' Instead, the reader feels the details of a place or a homeland that once existed, with its trees, breeze, buildings, and villages. This is a kind of topographical record of the Palestinian land, of the Palestinian cities and villages that later on were destroyed, rebuilt, and renamed by the Israeli colonialists. Fawal is inserting and bringing the names of the lost Palestinian cities back in his narrative, this is what Ashcroft calls postcolonial transformation that involves the insertion of "a contestatory voice" and a 
different version of the colonial historical discourse (2001, 103). Thus, Fawal figuratively retrieves the topography of Ardallah, i.e. Palestine:

Built 2500 feet above sea level, Ardallah was a natural landmark. Between Ardallah and the Mediterranean sea lay Jaffa, Lydda, and Ramleh, which were surrounded by hundreds of orange groves; between Ardallah and the highlands lay hundreds of Arab villages surrounded by fig and olive groves and pasture lands. $(1998,20)$

Reflecting on the names and borders of Palestine, Krämer maintains that in the context of the Jewish-Arab conflict over Palestine, places and their names have acquired a great significance to all efforts trying to legitimize historical rights to the land. To be able to establish the names of things is an indicator of political and cultural power. Thus, the various terms utilized to designate the land of Palestine reflect prevailing power relations. The Jewish claim to Palestine as the Land of Israel (Eretz Yisrael) bases itself on biblical narratives and affirms the constant presence of the Jewish people on this land. Krämer views this perspective as both distorted and distorting, as it affects the presentation of the land, its people, and its history: "it places the Jews at the center, pushing all other population groups (even if and when they formed a majority) into the background, if it considers them at all" $(2008,2)$. As a result, he states, "Palestine or Eretz Israel, offers a textbook case of the territorialization of history, in which political claims are anchored in historical geography" (3). On a similar vein, in his narration of the Palestinian land, Fawal offers a reterritorialization of history and geography where he brings all the marginalized groups and neglected facts back to the center.

For Palestine to be 'a land without a people for a people without a land,' the Israelis expelled the majority of the Palestinians to render their vision into a reality. Evidence of Palestinian existence had to be erased through the desertification of Palestinian land to prove the Zionist claim of making the desert prosper. This has been systematically done since 1948 with the Israeli military and settlement activities uprooting hundreds of thousands of Palestinian farms and trees especially olive and orange trees (Massad 2006, 176). Himself an Israeli professor, Israel Shahak, states that:

The truth about Arab settlement which used to exist before 1948, is one of the most guarded secrets of Israeli life [...] so that the accepted official myth of 'an empty country' can be taught and 
accepted in the Israeli schools and told to visitors. [...] This falsification is especially grave as it is accepted universally, outside the Middle East, and because the villages were destroyed completely, with their houses, garden walls, and even cemeteries, so that literally a stone does not remain standing, and visitors are passing and being told that "it was all desert." (qtd. in Massad 2006, 39)

Therefore, Fawal is attempting to subvert this 'falsification' through addressing the Western readers offering them another narrative in which he presents the Palestinian story and the Palestinians' version of this land. Later on through the memory of Amin's house, Fawal again reclaims the identity of these Palestinian houses which are hundreds of years old:

the thick muddy looking walls had grass growing on them and looked as old as the Roman arch [...] women sat in knots on the flat rooftops or against walls. They gossiped and darned clothes or combed and braided their waist-length hair. Smoke rose from behind an enclosure where a woman crouched to bake her bread [...] children jumped rope and played hopscotch. (Fawal 1998, 2728)

These details of the place not only affirm the existence of Palestinians on their land, but also represent and reclaim the hundreds of years that Palestinian cultural identity existed and flourished in this place. Thus, this is the narrative identity of the place, of the people through their daily lives as portrayed in the novel: women darning, combing, baking, children playing, etc. These are the signs of a people's culture on their land that is far from being arid or deserted. Describing Al-Andalus Hotel, the narrator says, "tables were covered with white cloths. The crystal glasses and silverware glistened. The entire garden, on both sides of the canopied dance floor, glittered with colored lights strung between the big, tall, hundred-year-old-trees" (Fawal 1998, 37). Even the name of the hotel "Al-Andalus" recalls the memory of a lost Arab territory that draws an affinity with the more recently lost Palestine.

\section{Zionist Colonial Discourse}

Documenting samples of Zionist discourse about Palestine in the period from 1865 to 1920 , Said cites some discourse makers such as those stated by C.R. 
Conder in his "Present Condition of Palestine." He describes the native peasantry as "brutally ignorant, fanatical, stupid, and above all, inveterate liars, which can only be found in Orientals" (qtd in Said 1979, 80). Lord Kitchener also writes in the Survey of Galilee: "we hope to rescue from the hands of that ruthless destroyer, the uneducated Arab [...] the synagogue of Capernaum" (qtd in Said 1979, 80). Against such derogatory misrepresentations, Palestinian literature writes back. In the novel, Fawal is refuting such colonial claims by depicting Palestinians as well-educated doctors, thoughtful teachers, lawyers, students, skillful peasants and workers, passionate lovers, stressing the prestigious lifestyle which Palestinians led in their homeland before the ominous advent of Zionist occupation.

As Abu-Lughod states that the battle for determining the fate of Palestine has been fought in Europe and the US, Palestinian Arabs and European Jewish settlers (later on Israeli settlers) confronted each other daily for the retention of the national patrimony, or for its possession respectively:

In important respects the battle for the consciousness [...] of outsiders turned out to be crucial in determining the favorable outcome of the first and second major 'battles' for Palestine: that of 1948 [...] and that of 1967. [...] The Declaration of Principles [1993] signified Israel's success in finally 'winning the war' against the Palestinians. [...] The issue now is the extent to which the evolving discourse on the continuing contest, albeit in altered form, will bear the imprint of the hardened discourse of the past. (Abu-Lughod 1995, 1)

Fawal, like other Palestinian writers writing in English targeting a wider American and Western readership, is trying to erase and refute that 'hardened discourse of the past' by creating their own discourse, by inserting the Palestinian version of the history of the land of Palestine in their works.

\section{Pre-Colonial Memory of Al-Quds}

Jerusalem, or Al-Quds, is of extreme importance to Muslims, Jews, and Christians. Thus, another important reclaiming of the national identity of the Palestinian land is through Yousif's visit to the sacred city of Al-Quds with his mother, who was visiting her sick sister Widad; this was her hometown. She wanted to light a candle at the Qiyameh, Holy Sepulchre and see her parents. The narrator tells how some of Yousif"s "happiest recollections resonated around 
this sacred and blessed city of shrines, temples, minarets, and domes. From childhood, he had loved everything about Jerusalem: the old and the new, the visits with his grandparents in the old district of Musrara and with his cousins up at modern Qatamon" (Fawal 1998, 101). This description of the holy city, with its sounds and smells, is indeed a reaffirmation of the Palestinian identity of the city. It is the city of churches and mosques, of rabbis, priests, and shaykhs, the city of the old sacred places and the new modern buildings; it was Palestinian with all of its details.

Jerusalem in particular is very central to the Palestinians' self-image. As Rashid Khalidi rightly maintains, it is important today as a space, and historically, over time, as an anchor for identity (Khalidi 1997, 18). Jerusalem, apart from its religious prominence, was also important for the inhabitants of Palestine as an administrative center, all the more so after 1874, when it became the capital of an independent sanjaq, which sent one deputy to the Ottoman parliaments and three to those of 1908-1918. In his significant book Palestinian Identity (1997), Khalidi further explains how this sense of Palestine as a country went back to the "Fada'l al-Quds" (merits of Jerusalem) literature which portrayed Jerusalem and other holy sites and notable places throughout Palestine. This includes the historical cities of Hebron, Jericho, Bethlehem, Nablus, alRamla, Safad, Ascalon, Acre, Gaza, and Nazareth. All such cities were remarkable sites for pilgrims and visitors who get to experience Palestine from within, and for the devout and inquisitive in general elsewhere. Kahlidi points out that these names suggest that a clear idea of the rough boundaries of Palestine are in essence "a sort of sacred - if not yet a national — space [which] already existed in the minds of authors and readers of this Islamic devotional literature. A similar idea existed for Christians, as well as for Jews" (Kahlidi 1997, 29).

Jerusalem was also significant for its cultural life. The press, schools, clubs, political parties, and other aspects of intellectual life all had a massive impact on the cultural richness of the city (Khalidi 1997, 35). The novel sheds some light on this cultural dimension like, for example, when Yousif and his mother visit the Khalidiyeh Library at the corner of the Jewish Quarter (Fawal 1998, 105). It is significant to observe how Rashid Khalidi got the idea for his important book during his involvement in the restoration of the Khalidiyeh family library in Jerusalem that gradually led him to the idea of exploring the intellectual history of Jerusalem (Khalidi 1997, vii). Khalidi also stresses a unique source for understanding Jerusalem's cultural life by the end of the $19^{\text {th }}$ century, which was the holding of family libraries in Jerusalem, such as Al-maktaba al-khalidiyya (Khalidiyeh Library) and Al-maktaba al-budayriyya (Budayriyya Library), 
beside Maktabat-ul-Aqsa (Al-Aqsa Library) (1997, 42). Unfortunately, such facts were intentionally obliterated by Zionist European settlers who expropriate and re-label antiquities to serve their own interests. They can impose their authority on narratives that give "weight to selected strata, thereby successfully manipulating both spatial and temporal aspects of identity, in pursuit of a clear nationalist political agenda. Their success can be seen from the tides of foreign tourists that choke the narrow alleys of the Old City for much of the year, most of them in groups led by Israeli tour guides propagating a specific version of the city's history" (Khalidi 1997, 18). Furthermore, Khalidi inquires how a Palestinian version would look like instead, wondering about the possibility of producing a multidimensional narrative that would reproduce the whole history of Jerusalem instead of reducing the complexity of the city's history to a single narrow dimension $(1997,18)$. Thus, it could be said that Fawal responds to such inquiries through inserting a narrative of the history of the land of Palestine with all of its holy cities and sites in the novel, offering a new version that subverts the hegemonic colonial one. Fawal's narrative is an archival documentation not only of the history of the Holy City, but also of its topography and cultural life that the Israeli settlers have been keen on erasing.

\section{Pre-Nakba Zionist Aggression}

In order to subvert such faulty Zionist representations of Palestine to the American and Western readership, the novel, on the other hand, documents the terrorism that Zionists have systematically initiated and escalated in Palestinian cities during those days before nakba. For example, the novel sets Jerusalem as the scene for many explosions designed by Zionists. Some of those explosions take place while Yousif and his mother are actually there in the city: "down the street the bomb went off with a horrible, deafening blast. But the screaming was even louder than the sound of the explosion" (Fawal 1998, 104). In their rush to escape, Yousif and his mother also pass by King David Hotel, "which the Zionist underground terrorist organization, the Irgun, had bombed fourteen months earlier, killing ninety-six innocent people, wounding many more, and shocking the whole civilized world" (107). In a later scene again, Yousif and his mother witness another devastating explosion of two barrels of dynamite that exploded "with a deafening roar. [...] Spilled gas and oil quickly burst into flames" (110). The heartbreaking damage and casualties caused by such explosions is unfathomable. Moreover, in an attempt to document the horridness of the scene, one photographer tries recording the events, but, unfortunately, only to add to the scene's gruesomeness. Yousif sees the man's camera twisted and "tongues 
of fire lapping up his legs [...] touched and horrified Yousif $[\ldots]$ saw that the man had already been charred. Fire was consuming him like a bag of bones" (Fawal 1998, 108). A few seconds later, "both sides of the street were littered with bodies. [...] The stink of gas, rubber, cordite, and flesh filled the air" (109). The novel, thus, alludes to the fact that the murdering of the photographer is ultimately symbolic of how Zionist colonialists constantly seek to hide all traces to their crimes.

Hence, it is through such diverse atrocities that Zionists tried to 'dePalestinize' Jerusalem and other cities while intimidating their inhabitants to leave their native land. This uncovering of what happened in the holy city and the atrocities committed by Zionist colonialists is Fawal's method of overturning false Zionist claims often propagated to Western readers through Zionist-led media platforms. Nevertheless, Edward Said observes how Israel is often represented in the American public discourse and worldwide as a nation in search of peace, while the Arabs are "bent on extermination, and prey to irrational violence" (1979, xiv). Said points out that the Middle East provides evidence of a direct connection between media practices and public policy where media representations could easily reinforce the use of force and brutality against native societies. Trying to dismantle such stereotypical images especially for the American reader, Fawal, on the contrary, portrays Palestinians as individuals seeking peace and development rather than violence or chaos. For instance, Yousif is represented as a peaceful young man whose heart is in pain for all the victims of such aggressive explosions. Moreover, early in the novel, when events escalated in 1947, Yousif also supports his father who adamantly refuses to use an allocated sum of money to buy weapons since the people of Ardallah had originally decided to save this sum to build a hospital instead.

\section{Pre-Colonial Memory of Haifa and Jaffa}

In order to offer an authentic representation to his readers, Fawal recurrently refers to historical facts about prominent cities, most notably are Haifa and Jaffa. This includes the narration of Haifa 'exodus' or the burning of Jaffa by Yousif's relatives who came seeking shelter to Ardallah after the horrific events they witnessed. Moreover, this is represented also through Yousif's visits to his cousin, Bassim, on the hill where Palestinian fighters were defending Ardallah against Zionist attacks; Yousif could see

Jaffa, a town as Arab as London is British. Yet at its harbor, ship after ship come full of Jewish refugees bent on making Jaffa their 
own! It boggled his mind that the Jews could even think it possible. Palestine was theirs but not his? Ridiculous! [...] Did the Jewish immigrants grow up in Palestine? Did they have an inalienable birthright to it but he didn't? What a travesty on logic! Did they play on these hills and in these valleys? [...] did they pick almonds and figs and olives and oranges off the trees in the plush orchards that dotted the land of Palestine? did they swim on the shores of Jaffa and Haifa and float on the salty waters of the Dead Sea? (Fawal 1998, 277; italics mine)

Such rhetorical questions help alert Western readers to the false claims of Zionists to the land by offering facts on the ground which would be more appealing to the Western mentality. According to Khalidi, Haifa and Jaffa were centers of commercial, cultural, and intellectual activities. By 1948, both cities had the largest Arab population in any of the cities in the country. He affirms that they had dynamism in so many spheres that "significantly affected the shaping of Palestinian identity" (Khalidi 1997, 36). For Palestinians, those dearly cherished cities were political, social, economic, and cultural beacons. That is why they were among the primary targets of the Zionist colonization of Palestine. Hence, it is a logical outcome to find Haifa and Jaffa, along with Jerusalem, among the recurrent motifs in Palestinian literature. The burning of Jaffa, the expulsion from Haifa, and the recurrent explosions in Jerusalem are all among the common scenes in Palestinian literature.

Yousif, with his attachment to the Palestinian land with all of its details, asks questions that reclaim and reaffirm the Arab identity not only of Jaffa and Haifa, but the whole of Palestine. Fawal attempts to illuminate the more hidden, suppressed, marginalized aspects of Palestinian history and of the land of Palestine itself. In order to be convincing to his American readership, he is archiving the existence of Palestinians through their daily lives inside Palestine. He offers, thus, the Palestinian version of the story of Palestine that he believes has been forced into silence by the Israeli colonial discourse and was not allowed to reach the Western reader who, on the other hand, has usually been offered the manipulated Israeli version alone. Massad even observes how Israeli propaganda sometimes proposes that Palestinians, after all, had emigrated to Palestine seeking a more revived economic climate which was brought about by European Jewish colonization $(2006,25)$. 


\section{Reclaiming Palestinian Cultural Identity}

In an interview with Liana Badr, Palestinian national poet Mahmoud Darwish states "I am disconcerted by the absence of the place, of its veritable attributes, in a poetry that pretends to celebrate it. I don't find in Palestinian poetry the flora and fauna, the landscape, in other words the real Palestine" (qtd. in Khamis and Rahman 2008, 3). In Fawal's novel, however, the flora and fauna and the landscape of Palestine are very present, and this is part of reclaiming the cultural and national identity of the land. Palestinians have a sacred relation to the land and this is clear through the novel's portrayal of the richness of Palestinian lands frequently referring to the trees, fruits, and orchards. As Ghassan Kanafani entitles one of his famous short stories "The Land of the Sad Oranges" (1958), Fawal is similarly keen on documenting the fact that Palestine was a major exporter of the world's oranges before 1948. Yousif's mother, for example, exclaims as she watches two men unload a pickup truck packed with boxes of oranges, which were a gift from a family friend they had visited a few days earlier: "the stack of boxes was now getting taller than the men" (Fawal 1998, 56). The act of Palestinian generosity, the fertility of the land, and the expertise of the Palestinians who planted the land are all foregrounded through the narrative. Later on, the thought of war and the taste of oranges reminded Yousif that "the big, juicy, fragrant Jaffa orange was Winston Churchill's favorite fruit [...] during World War II, Churchill always had special oranges shipped to him from Palestine" (57).

The novel moves from the memory of Jaffa's orange produce to the memory of Palestinian food in general. As an integral cultural feature, food is a signifier and marker of identity. Roland Barthes clarifies that food constitutes sets of information; it signifies "a system of communication, a body of images, a protocol of usages, situations, and behavior" $(1961,24)$. He explains that food "brings the memory of the soil" (27). Every country has its own type of food with its unique ingredients brought from the soil of that country. Furthermore, the methods of how such food is prepared shed light on the lifestyle, customs, and culture at large. Early in the novel, when Dr. Safi celebrates moving to his new villa, most families in Ardallah are keen to come bringing different types of Palestinian national food, in particular manasef: "women began to arrive from all directions carrying manasef" (Fawal 1998, 11).

Through this celebration, Fawal also stresses the intimate relationships among the families of different religions. The wooden bowls of manasef 
were brought by Christian and Muslim families; by rich and poor [...] the family of Moshe and Sarah Sh'lan, Isaac's parents [...] instead of contributing the usual manasef, they had ordered two large trays of kinafeh from Nablus - a town twenty miles to the northeast and famous for its pastries - and paid a taxi driver an outrageous fare to drive all the way to pick them up. $(1998,11)$

On other occasions in the novel, the narrator frequently speaks about traditional Palestinian dishes using their Arabic names, such as mujadarah, maklouba kinafeh, hummus, manasef with all its typical ingredients. This includes lamb, rice, bread, maraca (soup), and fried pine nuts. Referring to pine nuts is significant as well since the Palestinian pine tree is also another important national symbol. Traditional methods of preparing such meals is also delineated in an endeavour to further preserve the Palestinian food memory, another effective reclaiming of the Palestinian cultural identity at large. However, in their incessant attempts to obliterate Palestinian cultural features, many Israelis in the novel would claim their ownership of such meals instead. Thus, throughout the novel, Fawal intentionally asserts the Palestinian identity of the native cultural heritage through not only the reference to traditional dishes and their age-old recipes, but also other aspects, such as education, art, and music.

Fawal documents information about school systems, churches, universities, banks, prestigious hotels, and restaurants to affirm that Palestine before the nakba was already a modern state. He also portrays how Palestinians used to celebrate different social occasions such as weddings, graduation ceremonies, and funerals. The traditional songs and customs of such events are equally highlighted. He even delineates how women used to dress: "although the great majority of Arab women in town did wear modern western dresses, most were on the conservative side, and quite a few still wore the traditional ankle-length and heavily embroidered native costumes" (Fawal 1998, 17). Significantly, Fawal did not forget to document and reclaim the older Palestinian national anthem which was written by the Palestinian poet Ibraheem Touqan-older brother of Fadwa Touqan, Palestine's national poetess. It was announced as the official national anthem in 1937.

Moreover, commenting on the earlier British colonization, the people of Ardallah are portrayed while being imprisoned by British soldiers inside the Roman Catholic Church after inspecting Palestinian houses for holding weapons. While Ustaz Hakim was giving a speech commenting on the escalating events at that time, one of the crowd shouts "Long Live Palestine" and another 
starts chanting "Mowtini" (my homeland) before the whole crowd in the church sings along:

\author{
Mowtini, Mowtini, \\ Glory and beauty, \\ Sublimity and splendor, \\ Are in your hills, \\ We, young men, will never get tired, \\ Our concern is to be either independent or annihilated. \\ We would rather drink death, \\ Than be slaves to our enemy. (Fawal 1998, 192)
}

Beside, being part of the cultural heritage of Palestine, this traditional defiant and patriotic song is also a proof that Palestinians are used to fighting and resisting different forms of colonization across their history.

\title{
Pre-Nakba Historical Context
}

In this archival novel, Fawal documents Palestinian resistance through significant historical events and figures, most prominently national heroes and martyrs. Through Basim, Yousif's cousin, Fawal documents Palestinian armed resistance and how people of Ardallah were raising fund for arms to protect the city. This is a counter discourse for another Zionist myth that represents Palestinians as meek sellers of their lands. For example, in his book Palestinian Collective Memory and National Identity (2009), published by the Hebrew University of Jerusalem, Meir Litvak represents the Israeli colonial discourse which insists that "the weakness of Palestinian national identity and cohesion [is seen through] the sale of land to Jews by Palestinian landlords and the clandestine cooperation of a large number of Palestinians with the Zionists, mostly for financial benefit" $(2009,3)$. This is a typical discourse that Israeli colonialists often propagate not only in Europe and the US, but even in neighbouring Arab countries. Some Arabs, especially the young generation, circulate such myths of cowardice and greediness ignoring the long history of Palestinian resistance being unaware of the misery that the majority of Palestinians have suffered. This lack of awareness negatively affects Arab solidarity with the Palestinian cause, in consequence. Hence, the documentation of some horrendous crimes committed by Zionist colonialists in the novel, such as the Deir Yassin massacre and the atrocities of Haifa and Jaffa exodus, is central to the understanding of the Palestinian struggle. Thus, through narrating 
such incidents, Fawal is crossing borders of misunderstanding and building bridges of understanding, sympathy, and support for the Palestinian cause instead.

For example, defying deceitful Israeli colonial discourse, Fawal documents significant painful national wounds while simultaneously documenting the Palestinian resistive efforts. Through the figure of Abd al-Qadir Al-Husayni, a prominent figure of Palestinian resisitance, Fawal is asserting the national identity of Palestinians as freedom fighters and revolutionaries. It is through him also that Fawal documents important historical events and fights such as the battle of Bab-al-Wad:

In five weeks the British would be gone by May $15^{\text {th }}$ and the battle for the control of Jerusalem was already raging [...] the Palestinians, led by their ablest commander, Abd al-Qadir, had repeatedly pinned them down at the bottleneck at Bab al Wad. [...] Abd al Qadir - an honest man doing honest work. [...] Handsome, stout, and with bandoleer crisis-crossing his chest, he looked like the Palestinians' best hope to thwart Zionists' pipe dream. $(1998,200)$

Fawal reveals the collusion between British and Zionist colonialists as they evacuate Palestine in May, instead of August, thus, before the time designated by the UN Resolution. He represents the character of Al-Husayni in contrast to the stereotypical configurations of Palestinians often disseminated in Israeli colonial discourse. He also documents the Palestinian Revolt and the anti-Zionist immigration movement (1936-1939) upon which the British government issued a White Paper in 1939 that yielded to Arab demands. Several of such historical events are frequently overlooked within the colonial discourse. Thus, Abdelwahab Elmessiri elaborates on how discourse ultimately serves exploitation schemes. He asserts that part of the tactics of colonial discourse is to isolate terms and phenomena from their historical contexts (Elmessiri 2003, 42). Elmessiri argues that the Zionist entity was forcefully implanted by imperial powers as "a strange human block in the midst of the Arab world, a block which turned to a state that works for the imperial sponsor" (42). He states that the conflict is rooted in the displacement of Palestinians by colonial settlers which took place as a result of the Arabs' refusal of the UN partition plan of Palestine in 1948 (42). Consequently, colonialists resorted to the representation of Arabs as 
'barbarians' who kill the peaceful settlers and hence the result turns into a cause and Zionism is thus presented not as a settler colonialist movement but as an achievement of the Jewish dream of returning to the promised land while resistance is presented as unjustified terrorism and the Israeli attacks are presented as self-defense and the Israeli army is presented as the Israeli defense army. (42)

Furthermore, for Frantz Fanon, the struggle against colonialism involves claiming back the history of colonized people away from the distorted version produced by the colonizer who constantly aims at tarnishing it. Thus, Fanon calls for "a passionate research [...] directed by the secret hope of discovering beyond the misery of today, beyond self-contempt [...] some very beautiful and splendid era whose existence rehabilitates us both in regard to ourselves and in regard to others" $(1994,37)$. Such a 'passionate research' for 'hidden histories' is similarly reiterated by Stuart Hall who asserts that it is rather a practice that entails "the production of identity [...]. We should not, for a moment, underestimate or neglect the importance of the act of the imaginative rediscovery which this conception of a rediscovered, essential identity entails" (393). Moreover, Bill Ashcroft emphasizes that the transformation of history stands as one of the most strategic and powerfully effective modes of cultural resistance. A key strategy in this transformation is "the interpolation of historical discourse. This involves not only the insertion of a contestatory voice, a different version [...] but an entry into the discourse which disrupts its discursive features and reveals the limitations of the discourse itself [...] it is in the literary texts that some of the most disruptive and evocative potentialities of historical interpolation may occur" (Ashcroft 2001, 103).

\section{Conclusion}

For Palestinians, identity is the most painful aspect of their history. Khalidi emphasizes that the quintessential Palestinian experience takes place at borders, airports, checkpoints, at any one of those many modern barriers where identities are checked and verified. Borders are a problem for Palestinians "since their identity not only is subject to question by the powers that be; but also is in many contexts suspect almost by definition" (Khalidi 2). At those barriers, every Palestinian is exposed to harassment and exclusion because of his or her identity. Khalidi refers to the ominous words often said by border guards "step out of line and follow me" as depressingly familiar to Palestinians at crossing points amongst several other painful stories of exclusion and denial that Palestinians 
could easily relate to (3). Fawal is one of those border crossers who has suffered such agony related to the Palestinian identity, and maybe such painful incidents of border crossing pushed him to write On the Hills of God to reclaim Palestinian national and cultural identities.

In conclusion, Fawal represents through his novel a narrative where the domains of history, memory, identity, and literature are unmistakably interrelated. Highlighting the significant connection between history and literature, Sontag stresses that "literature might be described as the history of human responsiveness to what is alive and what is moribund as cultures evolve and interact with one another" (qtd. in Popova 2013, n. pag.). Thus, throughout their national and cultural struggles, Palestinian authors have produced literature that narrates and writes back to repressive colonial representations. For Edward Said nations are formed through narrations. The narrative is a method which colonized people use to "assert their own identity and the existence of their own history" (1993, xiii). For him, culture is ultimately "a source of identity... It can even be a battleground on which causes expose themselves to the light of day and contend with one another" (xiii). One can say that literature is a source of history as it offers an alternative disruptive version of hegemonic colonial delineations. The fictional narrative of Fawal does not only provide a historical account of Palestine, but it is a kind of topographical record of the Palestinian land, of the Palestinian cities and villages that were destroyed, rebuilt and renamed by Israeli colonialization in an attempt to obliterate the people's original identity. Identities, as Hall elaborates, are constructions that arise from the "narrativization of the self" $(1996,4)$. Fawal's novel, thus, 'narrates' the Palestinian land with its cherished details. It narrates the loss and dispossession that Palestinians experience hoping to re-possess in literature what has been lost in reality.

Although the actual physical crossing of borders is usually a painful experience to most Palestinians, some of them, nevertheless, attempt to bridge such borders to achieve a better understanding of their cause through their literary productions. Literature, as Sontag maintains, is "the passport to enter a larger life; that is the zone of freedom" (qtd. in Popova 2013, n. pag.). Fawal metaphorically crosses borders of time and space back to Palestine to defy oppressive Israeli representations of the Palestinians and their existence on their homeland prior to the establishment of Israel. However, as Paul Ricoeur emphasizes, history begins and ends with the reciting of a tale (Ricoeur 1995, 224). He asserts that narrative is a redefining of what is already defined, a reinterpretation of what is already interpreted (224). He adds that the future is 
"guaranteed by the ability to possess a narrative identity, to collect the past in historical or fictive form" (224). Hence, although Israel often defines and portrays Palestinians for American and Western audiences in derogatory misrepresentations, Fawal is able to 'redefine' and 'reinterpret' the Palestinian image in an attempt to guarantee a more promising future when he, and other members of the Palestinian diaspora, are able to cross the borders back and return to Palestine.

\section{Works Cited}

"About the Author." 2006. On the Hills of God, 448. Montgomery: New South Books.

Abu-Lughod, Ibrahim. 1995. "Forward." In Discourse and Palestine: Power, Text and Context, edited by Annelies Moors, Toine Van Teeffelen, Sharif Kanaana, and Ilham Abu Ghazaleh, 1-2. Amsterdam: Het Spinhuis.

Alexander, Edward. 1989. "Professor of Terror." Commentary, August 1989.

$<$ https://www.commentarymagazine.com/articles/edward-alexander/ professor-of-terror/>.

Ashcroft, Bill. 2001. Post-Colonial Transformation. London: Routledge.

Barker, Chris. 2000. Cultural Studies: Theory and Practice. London: SAGE Publication Inc.

Barthes, Roland. 1961. "Toward a Psychosociology of Contemporary Food Consumption." In Food and Culture, 2013, edited by Carol Counihum, Penny Van Esterik, and Alice P. Julier, 23-30. London: Routledge.

Bhabha, Homi. 1990. Nation and Narration. London: Routledge.

Brandabur, Clare. 2002. "Voices from Exile: Two Novels of Palestinian History." Edebiyat 13, no. 1: 81-86.

$<$ https://doi.org/10.1080/0364650022000047650>.

Cleary, Joe. 2002. Literature, Partition and the Nation State: Culture and Conflict in Ireland, Israel and Palestine. Cambridge: Cambridge UP.

Elmesseri, Abdelwahab M. 2003. Fi al-khetab wa al-mustalah alsuhyuni: dirasa nazariya wa tatbiqiya (In the Zionist Terminology and Discourse: a Theoretical and Practical Study). Cairo: Dar Al-Shorouk.

Fanon, Frantz 1994. "On National Culture.” In Colonial Discourse and Postcolonial Theory, edited by Patrick Williams and Laura Chrisman, 36-52. New York: Columbia UP.

Fawal, Ibrahim. 1998. On the Hills of God. Montgomery: New South books. 
Gordon, Lora. 2007. "On the Hills of God." Review of On the Hills of God, by Ibrahim Fawal. Electronic Intifada, July 23, 2007. $<$ https://electronicintifada.net/content/book-review-hills-god/3523>.

Hall, Stuart. 1992. "Cultural Studies and its Theoretical Legacies." In Cultural Studies, edited by L. Grossberg, C. Nelson, and P. Treichler, 277-94. London and New York: Routledge.

-----. 1994. "Cultural Identity and Diaspora." In Colonial Discourse and Postcolonial Theory, edited by Patrick Williams and Laura Chrisman, 392-403. New York: Columbia UP.

----. 1996. "Who Needs an Identity." In Questions of Cultural Identities, edited by Stuart Hall and Paul Du Gay, 1-18. London: SAGE Publications Ltd.

Jabra, Jabra Ibrahim. 1979. "The Palestinian Exile as a Writer." Journal of Palestine Studies 8, no. 2: 77-87.

Khalidi, Rashid. 1997. Palestinian Identity. New York: Columbia University Press.

Khamis, Hala and Najat Rahman, eds. 2008. Mahmoud Darwish: Exile's Poet, Critical Essays. Massachusetts: Olive Branch Press.

Kayyali, Abdul-Wahab. 1977. "Zionism and Imperialism: The Historical Origins." Journal of Palestine Studies 6, no. 3: 98-112.

Kolosov, Vladimir. 2015. "Theoretical Approaches in the Study of Borders." In Introduction to Border Studies, edited by Sergi Sevastiano, Jussi Laine, and Anton Kireev, 33-61. Vladivostok: Far Eastern Federal University. $<$ https://ojkum.ru/images/knigi/Introduction_to_Border_Studies3>.

Krämer, Gudrun. 2008. A History of Palestine: from the Ottoman Conquest to the Founding of the State of Israel. New Jersey: Princeton University Press.

Kuznetsov, Anatolii. "Symbolic Boundaries of Social Systems." In Introduction to Border Studies, edited by Sergi Sevastiano, Jussi Laine, and Anton Kireev, 80-97. Vladivostok: Far Eastern Federal University.

$<$ https://ojkum.ru/images/knigi/Introduction_to_Border_Studies3 $>$.

Lee, Michael. 1999. "Book Review: On the Hills of God." Washington Report on Middle East Affairs, June 1999: 123-24. <https://www.wrmea.org/1999june/on-the-hills-of god.html>.

Litvak, Meir. 2009. Palestinian Collective Memory and National Identity. Palgrave Macmillan: New York.

Massad, Joseph. 2006. The Persistence of the Palestinian Question. New York: Routledge.

Ostle, Robin. 2006. "Forward." On the Hills of God, 1-8. Montgomery: New South Books. 
Pappé, Ilan. 2009 "De-Terrorising the Palestinian National Struggle: The Roadmap to Peace." Critical Studies on Terrorism 2, no. 2 (August): 127-46. Popova, Maria. 2013. "Susan Sontag on Literature and Freedom." Brain Pickings. October 22, 2013. <https://www.brainpickings.org/2013/10/22/ susan-sontag-on-literature-and-freedom/ $>$.

Prior, Michael. 2005. "Zionism and the Challenge of Historical Truth and Morality." Speaking the Truth: Zionism, Israel and Occupation, edited by Michael Prior, 13-50. Massachusetts: Olive Branch Press.

Ricoeur, Paul. 1995. “The Creativity of Language." In States of Mind: Dialogues with Contemporary Thinkers on the European Mind. Interview by Richard Kearney, 216-45. Manchester: Manchester UP.

Rossington, Michael and Anne Whitehead, eds. 2007. "Introduction." Theories of Memory. 1-18. Edinburgh: Edinburgh University Press Ltd.

Said, Edward. 1979. The Question of Palestine. New York: Vintage Books.

-----. 1993. Culture and Imperialism. New York: Alfred A. Knopf, Inc.

Sevastianov, Sergi. Jussi P. Laine, and Anton A. Kireev, eds. 2015. Introduction to Border Studies. Vladivostok: Far Eastern Federal University.

Shohat, Ella. 1995. "Exile, Diaspora, and Return: The Inscription of Palestine in Zionist Discourse." In Discourse and Palestine: Power, Text and Context, edited by Annelies Moors, Toine Van Teeffelen, Sharif Kanaan, and Ilham Abu Ghazaleh, 221-35. Amsterdam: Het Spinhuis.

Smith, Claudia Sadowski. 2002. "Introduction: Border Studies, Diaspora, and Theories of Globalization." In Globalization on the Line: Culture, Capital, and Citizenship at U.S. Borders, edited by Claudia Sadowski-Smith, 1-27. New York: Palgrave.

Turki, Fawaz. 1981. "Meaning in Palestinian History: Text and Context." Arab Studies Quarterly 3, no. 4: 371-83. 